\title{
Characterization and optimization of extracellular enzymes production by Aspergillus niger strains isolated from date by-products
}

\author{
Reda Bellaouchi ${ }^{1 *}$ D, Houssam Abouloifa ${ }^{1}$, Yahya Rokni ${ }^{1}$, Amina Hasnaoui ${ }^{1}$, Nabil Ghabbour ${ }^{1}$, Abdelkader Hakkou ${ }^{1}$, \\ Abdelmajid Bechchari ${ }^{2}$ and Abdeslam Asehraou'
}

\begin{abstract}
Background: This work aims to study the optimal conditions of the fermentation culture medium used for the production of extracellular enzymes (amylase, cellulase, lipase, and protease) from previously isolated Aspergillus niger strains in date by-products.

Results: The five most powerful isolates selected based on the zone of degradation formed on Petri plates by the substrate were subjected to the quantitative evaluation of their enzymatic production. All five strains showed almost similar API-ZYM profiles, with minor variations observed at the level of some specific enzyme expression. The production of cellulase and amylase was depending on $\mathrm{pH}$ and incubation temperatures. ASP2 strain demonstrated the high production rate of amylase (at pH 5 and $30^{\circ} \mathrm{C}$ ) and cellulase (at pH 6 and $30^{\circ} \mathrm{C}$ ) for $96 \mathrm{~h}$ of incubation.

Conclusion: The A. niger showed the ability to produce several extracellular enzymes and can be used in the valorization of different agroindustrial residues.
\end{abstract}

Keywords: Extracellular, Enzymes, Date by-products, Aspergillus niger

\section{Background}

Aspergillus niger is the most commonly used industrial Aspergillus species for the production of pharmaceuticals, food ingredients, and enzymes [1, 2]. It was the most important fungi used worldwide for biotechnological applications [3]. A. niger is known for its capacity to produce a broad range of enzymes related to the degradation of plant polysaccharides, such as cellulose, $x y-$ lan, xyloglucan, galactomannan, and pectin [4]. These enzymes are essential to convert the natural carbon sources of these fungi (mainly plant polymers) into small molecules that can be taken up into the cell and can be widely used in the industry [4].

\footnotetext{
* Correspondence: r.bellaouchi@ump.ac.ma

${ }^{1}$ Laboratory of Bioresources, Biotechnology, Ethnopharmacology and Health, Faculty of Sciences, Mohammed Premier University, 60000 Oujda, Morocco Full list of author information is available at the end of the article
}

Considering the substantial availability of highly rich date by-products at very low prices, the use of these wastes as raw material for different bioproduction could provide a profitable substrate for low-cost biotechnological productions. These date fruits are mainly composed of sugars, a low percentage of fat and protein [5, 6], and significant amounts of total dietary fibers (TDF) ( 7.81-13.63\% dry matter basis) [7]. A. niger strains isolated from this environment should have the necessary enzymatic activity to degrade these elements to produce their requirements in terms of carbon, nitrogen, vitamins, and amino acids.

As we know, the production and yield of the enzyme were influenced by many factors, including temperature, $\mathrm{pH}$, carbon, and nitrogen source $[8,9]$. The purpose of this study is the characterization of enzymatic production in different environmental conditions (incubation 
time, $\mathrm{pH}$, and $\mathrm{T}{ }^{\circ} \mathrm{C}$ ), using Aspergillus niger strains, isolated from undervalued dates and processed date byproducts [5].

\section{Methods}

\section{Fungal strains and culture conditions}

A total of 40 strains of Aspergillus niger used in this work were isolated from date by-products and identified in previous work [5]. One millimeter of each diluent was plated on the solidified PDA plates (Biokar, France) by streaking. The plates were incubated at $25{ }^{\circ} \mathrm{C}$ for $3-5$ days to ensure maximum fungal growth. Characteristic growth of $A$. niger (initially white, rapidly turning black) was subjected to microscopic observation. For microscopic identification, a drop of lactophenol blue was placed on a clean slide, with a fragment of the fungal growth, and observed under the microscope using a $\times 10$ then $\times 40$ objectives. The isolates obtained were given a number preceded by ASP. In this way, 40 isolates were purified and stored on inclined tubes of the PDA medium at $4{ }^{\circ} \mathrm{C}$ until they were used. These strains were routinely reactivated and cultured in PDA at $25{ }^{\circ} \mathrm{C}$ for 7 days before use.

\section{Screening extracellular enzymes from $A$. niger Cellulase activity}

The cellulase activity of $A$. niger strains was realized in Czapek-Dox agar medium containing sucrose $30 \mathrm{~g} / \mathrm{L}$, sodium nitrate $3 \mathrm{~g} / \mathrm{L}$, magnesium sulfate $0.5 \mathrm{~g} / \mathrm{L}$, potassium chloride $0.5 \mathrm{~g} / \mathrm{L}$, iron(III) sulfate $0.01 \mathrm{~g} / \mathrm{L}$, dipotassium hydrogen phosphate $1 \mathrm{~g} / \mathrm{L}$, agar $12 \mathrm{~g} / \mathrm{L}$, and carboxymethylcellulose (CMC) 1\% (w/v) (Sigma-Aldrich, USA). A. niger strains were inoculated with $5 \mathrm{~mm}$ of the mycelium at the center of the plate and incubated for 5 days at $25{ }^{\circ} \mathrm{C}$. After incubation, the cultures were flooded with a Congo red solution (0.2\%) and then bleached with $1 \mathrm{M} \mathrm{NaCl}$ for $15 \mathrm{~min}$. Clear zones obtained around the fungal colony indicated cellulolytic activity. All experiments were realized in triplicate.

\section{Amylase activity}

The amylase activity was evaluated by measuring the ability of $A$. niger strains to hydrolyze starch in the agar medium. $5 \mathrm{~mm}$ of mycelia from strains was placed in the YPD medium containing dextrose $1 \mathrm{~g} / \mathrm{L}$, yeast extract $0.1 \mathrm{~g} / \mathrm{L}$, peptone $0.5 \mathrm{~g} / \mathrm{L}$, and agar $16 \mathrm{~g} / \mathrm{L}$, and supplemented with $1 \%(\mathrm{w} / \mathrm{v})$ of soluble starch (Sigma-Aldrich, USA). After incubation at $25{ }^{\circ} \mathrm{C}$ for 5 days, the plates were flooded with a solution containing $1 \%$ iodine solution in $2 \%$ potassium iodide. Zone of clearance around the colony indicated amylase activity and was measured. The test was performed in triplicate.

\section{Lipase activity}

The lipase activity was detected in a medium containing peptone $10 \mathrm{~g} / \mathrm{L}, \mathrm{NaCl} 5 \mathrm{~g} / \mathrm{L}, \mathrm{CaCl}_{2} \cdot 2 \mathrm{H}_{2} \mathrm{O} 0.1 \mathrm{~g} / \mathrm{L}$, and agar $16 \mathrm{~g} / \mathrm{L}$ and autoclaved at $121{ }^{\circ} \mathrm{C}$ for $20 \mathrm{~min}$. Ten milliliters of Tween-20 was separately autoclaved and added into the medium and inoculated with $5 \mathrm{~mm}$ of mycelia from A. niger. After incubation at $25{ }^{\circ} \mathrm{C}$ for 5 days, the lipolytic activity was indicated by the appearance of a visible precipitate. All the assays were performed in triplicate.

\section{Protease activity}

Protease activity of $A$. niger strains was evaluated on YPD agar medium supplemented with $0.4 \%(\mathrm{w} / \mathrm{v})$ of gelatin (Sigma-Aldrich, USA), and the plates were inoculated with $5 \mathrm{~mm}$ of mycelia from strains. After incubation at $25{ }^{\circ} \mathrm{C}$ for 5 days, the plates were flooded with saturated aqueous ammonium sulfate. The clear zone around the fungal colony indicated the hydrolysis of gelatin. All tests were realized in triplicate.

\section{Semiquantification of extracellular enzymes from $A$. niger Inoculum preparation}

Five A. niger strains (ASP2, ASP6, ASP28, ASP31, and ASP32), selected for their high enzyme production, were initially cultured on PDA medium for 5 days at $25^{\circ} \mathrm{C}$. After incubation, a spore suspension was prepared by flooding the grown fungal cultures with $10 \mathrm{~mL}$ sterile distilled water. The spore concentration was adjusted to $5 \times 10^{6}$ spores $/ \mathrm{mL}$ using the Thoma cell counting chamber.

\section{Semiquantification of extracellular enzyme production}

An aliquot of $65 \mu \mathrm{L}$ of the spore suspension of $A$. niger strains was then delivered into the API-ZYM cupules (BioMerieux, France) and incubated at $37^{\circ} \mathrm{C}$ for $12 \mathrm{~h}$. One drop of ZYM A (25 g Tris-hydroxymethylaminomethane, $11 \mathrm{~mL} 37 \% \mathrm{HCl}, 10$ g sodium lauryl sulfate, $\left.100 \mathrm{~mL} \mathrm{H}_{2} \mathrm{O}\right)$ and ZYM B $(0.12 \mathrm{~g}$ Fast Blue BB, 50 $\mathrm{mL}$ methanol, $50 \mathrm{~mL}$ dimethylsulfoxide) reagents was added to the cupules, which were placed under white light for $10 \mathrm{~min}$. The API-ZYM test can detect 19 different enzymes and score their concentrations on a rating scale of $0-5$. Scoring was done using the API-ZYM ${ }^{\circ}$ color scale, in which $0=$ no enzyme, $1=5 \mathrm{nmol}, 2=10$ nmol, $3=20 \mathrm{nmol}, 4=30 \mathrm{nmol}$, and $5=40 \mathrm{nmol}$ or more.

\section{Quantification of amylase and cellulase activities of $A$. niger strains \\ Measurement of amylase and cellulase activities}

The quantitative evaluation of amylase activity was studied in $50-\mathrm{mL}$ flasks containing $25 \mathrm{~mL}$ of culture medium. The culture medium composition was $(\mathrm{g} / \mathrm{L})$ 
$\mathrm{NaNO}_{3} 3 \mathrm{~g}, \mathrm{MgSO}_{4} \cdot 7 \mathrm{H}_{2} \mathrm{O} 0.5 \mathrm{~g}, \mathrm{KCl} 5 \mathrm{~g}, \mathrm{KH}_{2} \mathrm{PO}_{4} 1 \mathrm{~g}$, $\mathrm{FeSO}_{4} \cdot 7 \quad \mathrm{H}_{2} \mathrm{O} 0.01 \mathrm{~g}$, and $\mathrm{CaCl}_{2} 0.1 \mathrm{~g}$, supplemented with $1 \%$ starch. On the other hand, the cellulase activity was studied on the liquid culture medium described by Hultin and Nordstr6m [10], supplemented with 1\% (w/ v) carboxymethylcellulose CMC (Sigma Aldrich Co, Germany). These flasks were then autoclaved at $121{ }^{\circ} \mathrm{C}$ for $15 \mathrm{~min}$ and cooled at room temperature. After sterilization, the flasks were inoculated with a spore suspension of $2 \times 10^{5}$ spores $/ \mathrm{mL}$ and incubated for 3 days in an orbital shaker (KS $4000 \mathrm{I}$ control) at $150 \mathrm{rpm}$. An uninoculated flask was used as a control.

The culture broth was filtered using Whatman filter paper $\mathrm{N}^{\circ} 1$ (Indiamart, India), and then, the filtrate was centrifuged at $8000 \mathrm{~g}$ for $10 \mathrm{~min}$ at $10{ }^{\circ} \mathrm{C}$. The culture supernatant $(1 \mathrm{~mL})$ was added to $1 \%(\mathrm{w} / \mathrm{v})$ starch for amylase activity and $1 \%(\mathrm{w} / \mathrm{v}) \mathrm{CMC}$ for cellulase activity measurement in $0.05 \mathrm{M}$ sodium acetate buffer ( $\mathrm{pH} 5.6,8$ $\mathrm{mL}$ ), and incubated at $50{ }^{\circ} \mathrm{C}$ for $30 \mathrm{~min}$.

Reducing sugars were determined based on the DNS method [11]. One unit of amylase and cellulase activity $(\mathrm{U})$ is defined as the amount of enzyme that liberated 1 $\mu \mathrm{mol}$ of $\mathrm{D}$-glucose from starch and $\mathrm{CMC}$ in a $1 \mu \mathrm{L}$ reaction mixture under the assay conditions.

\section{Biomass growth}

The fungal biomass was collected, after 7 days of incubation at $25{ }^{\circ} \mathrm{C}$, on Whatman grade 1 filter paper (Indiamart, India), and dried in an oven at $100{ }^{\circ} \mathrm{C}$ for $18 \mathrm{~h}$. The biomass of fungal culture was expressed as dry weight $(\mathrm{g} / \mathrm{L})$. All the tests were made in triplicate.

\section{Factors influencing the production of amylase and cellulase enzymes}

Effect of initial $\mathrm{pH}$ on production of amylase and cellulase activities

The effect of initial $\mathrm{pH}$ on the production of amylase and cellulase enzymes was evaluated on liquid culture. The medium broth of amylase and cellulase activities was adjusted of the initial $\mathrm{pH}$ of $3,4,5,6,7$, and 8 with hydrochloric acid $(4 \mathrm{M})$ and inoculated with $1 \%(\mathrm{v} / \mathrm{v})$ of $A$. niger ASP2. After inoculation, the cultures were incubated at $25^{\circ} \mathrm{C}$ for 7 days. Amylase and cellulase activities were measured. All tests were performed in triplicate.

\section{Effect of temperature on production of amylase and cellulase activities}

The effect of different temperatures on the production of amylase and cellulase enzymes was evaluated on liquid culture. The medium broth of amylase and cellulase activities was adjusted of the initial $\mathrm{pH} 7$ with hydrochloric acid $(4 \mathrm{M})$ and inoculated with $1 \%(\mathrm{v} / \mathrm{v})$ of A. niger ASP2. After inoculation, the cultures were incubated at different temperatures $(25,28,30,35,40$, and $45^{\circ} \mathrm{C}$ ) for 7 days. Amylase and cellulase activities were measured. All tests were performed in triplicate.

\section{Effect of incubation period on the production of amylase and cellulase activities}

The dynamic of production of amylase and cellulase enzymes by $A$. niger ASP2 strains was evaluated by the measurement of enzymatic activity in different incubation time. A. niger ASP2 strains were inoculated with $1 \%$ (v/v) in medium broth adjusted in $\mathrm{pH} 7$ with hydrochloric acid $(4 \mathrm{M})$ and cultivated at $25^{\circ} \mathrm{C}$. After 24, 48, $72,96,120,144$, and $168 \mathrm{~h}$ of incubation, the amylase and cellulase were determined. All assays were performed in triplicate.

\section{Statistical analysis}

Means were based on three replications. The values of different parameters were expressed as the mean \pm standard deviation. Student-Newman-Keuls test was performed using the statistical analysis package SPSS 10 for Windows (SPSS Inc., Chicago, USA) at $p<0.05$, to evaluate the significance of differences between mean values.

\section{Results}

\section{Qualitative of extracellular enzymes from A. niger}

The production of several enzymes by $A$. niger was detected in an agar medium containing a different carbon source, and the result is reported in Table 1 and Fig. 1. A. niger strains demonstrated the amylase, cellulase, and lipase activities by the hydrolysis of starch, cellulose, and Tween-20, respectively. Also, the amylase and cellulase activities dominated compared with the lipase activity in the percentage of strains. However, no protease activity was detected from all $A$. niger strains. Furthermore, the amylase, cellulase, and lipase activities were detected at different levels in strains from all date by-products. Hence, the $A$. niger strains isolated from date fruit, date paste, and date-seed-powder showed high productions of amylase and cellulase and to some degree lipase, to those isolated from date juice. On the other hand, the absence of enzyme production (i.e., protease) may be undetectable, or the reaction is not an absolute confirmation of a species inability to produce this particular enzyme, which could justify the non-detection of a protease enzyme on all strains tested despite the positive growth on this media. It could also be due to the ability of the fungus to use other materials in the medium other than the tested substrates.

Out of forty isolates, the strains ASP2, ASP6, and ASP31, and ASP2, ASP28, and ASP32, showing high activity for amylase (10.6, 9.3, and $9 \mathrm{~mm}$ ) and cellulase (10.3, 9.3, and $8.3 \mathrm{~mm}$ ) (Table 1), respectively, were selected for the semiquantitative analysis for enzyme production. The Aspergillus strains isolated from date 
Table 1 Hydrolytic activity (mm) of Aspergillus niger isolates, obtained from different date by-products

\begin{tabular}{|c|c|c|c|c|c|}
\hline \multirow{2}{*}{$\begin{array}{l}\text { A.niger } \\
\text { isolates }\end{array}$} & \multirow[t]{2}{*}{ Source } & \multicolumn{4}{|c|}{ Diameters (mm) } \\
\hline & & Starch & Gelatin & Cellulose & Tween-20 \\
\hline$\overline{A S P 1}$ & Date paste & $8.3 \pm 0.58^{c}$ & - & $4.3 \pm 0.58^{\mathrm{a}}$ & $4.3 \pm 0.58^{b}$ \\
\hline ASP2 & & $10.6 \pm 0.58^{d}$ & - & $10.3 \pm 0.58^{b}$ & $5.3 \pm 0.58^{b}$ \\
\hline ASP3 & & $4.3 \pm 0.58^{b}$ & - & $4.6 \pm 0.58^{\mathrm{a}}$ & - \\
\hline ASP4 & & - & - & $4.3 \pm 0.58^{a}$ & $4 \pm 1.00^{b}$ \\
\hline ASP5 & Date fruit & $8.3 \pm 0.58^{e}$ & - & $5.3 \pm 0.58^{c}$ & - \\
\hline ASP6 & & $9 \pm 0.00^{\mathrm{e}}$ & - & $5.6 \pm 0.58^{d}$ & - \\
\hline ASP7 & & $4.3 \pm 0.58^{b}$ & - & $5.6 \pm 1.15^{d}$ & - \\
\hline ASP8 & & $3.3 \pm 0.58^{b}$ & - & $3 \pm 1.00^{\mathrm{b}}$ & - \\
\hline ASP9 & & - & - & - & $5.3 \pm 0.58^{\mathrm{e}}$ \\
\hline ASP10 & & - & - & $5.3 \pm 0.58 b^{c}$ & - \\
\hline ASP11 & & $6.3 \pm 1.15^{d}$ & - & $6.3 \pm 0.58^{d}$ & $3.3 \pm 0.58^{b}$ \\
\hline ASP12 & & $3.3 \pm 1.15^{b}$ & - & - & - \\
\hline ASP13 & & - & - & - & - \\
\hline ASP14 & & - & - & $4.3 \pm 0.58^{\mathrm{bc}}$ & $3.3 \pm 0.58^{b}$ \\
\hline ASP15 & & - & - & - & - \\
\hline ASP16 & & - & - & $6.3 \pm 0.58^{d}$ & - \\
\hline ASP17 & & - & - & $6.3 \pm 0.58^{d}$ & $3 \pm 0.58^{b c}$ \\
\hline ASP18 & & $5.3 \pm 0.58^{c}$ & - & - & - \\
\hline ASP19 & & - & - & - & - \\
\hline ASP20 & & $3.6 \pm 0.58^{b}$ & - & $5.3 \pm 0.58^{\mathrm{bc}}$ & $4 \pm 0.00^{d}$ \\
\hline ASP21 & & $8 \pm 1.00^{\mathrm{e}}$ & - & - & - \\
\hline ASP22 & & - & - & - & $2.6 \pm 0.58^{b}$ \\
\hline ASP23 & & $8.3 \pm 0.58^{e}$ & - & - & - \\
\hline ASP24 & & - & - & - & $3.3 \pm 0.58^{b}$ \\
\hline ASP25 & & - & - & - & - \\
\hline ASP26 & Date-seed-powder & $7.3 \pm 0.58^{c}$ & - & $6 \pm 0.00^{b}$ & $3.3 \pm 0.58^{b}$ \\
\hline ASP27 & & $2.6 \pm 0.58^{a}$ & - & $7.3 \pm 0.58^{\mathrm{bc}}$ & $5.3 \pm 0.58^{c}$ \\
\hline ASP28 & & $3 \pm 0.00^{\mathrm{a}}$ & - & $8.3 \pm 0.58^{\mathrm{cd}}$ & - \\
\hline ASP29 & & $7.6 \pm 1.15^{c}$ & - & $4 \pm 0.00^{\mathrm{a}}$ & - \\
\hline ASP30 & & $5.3 \pm 0.58^{b}$ & - & $6.3 \pm 0.58^{b}$ & - \\
\hline ASP31 & & $9.3 \pm 0.58^{d}$ & - & $6 \pm 1.00^{\mathrm{b}}$ & $5 \pm 0.00^{c}$ \\
\hline ASP32 & & $7.3 \pm 0.58^{c}$ & - & $9.3 \pm 0.58^{d}$ & $3.3 \pm 0.58^{b}$ \\
\hline ASP33 & Date-flesh-powder & $4.6 \pm 0.58^{c}$ & - & - & - \\
\hline ASP34 & & $4 \pm 0.00^{b}$ & - & - & - \\
\hline ASP35 & & - & - & $3.6 \pm 0.58^{b}$ & $3.6 \pm 0.58^{b}$ \\
\hline ASP36 & & - & - & - & - \\
\hline ASP37 & Date juice & - & - & - & - \\
\hline ASP38 & & $3 \pm 1.00^{b}$ & - & - & - \\
\hline ASP39 & & - & - & - & $4.3 \pm 0.58^{b}$ \\
\hline ASP40 & & - & - & - & - \\
\hline
\end{tabular}

Results are means \pm SD $(n=3)$. Values of the same column, followed by the same letter, are not statistically different $(p<0.05)$ as measured by Student-Newman-Keuls test

"_" indicates no detected activity 


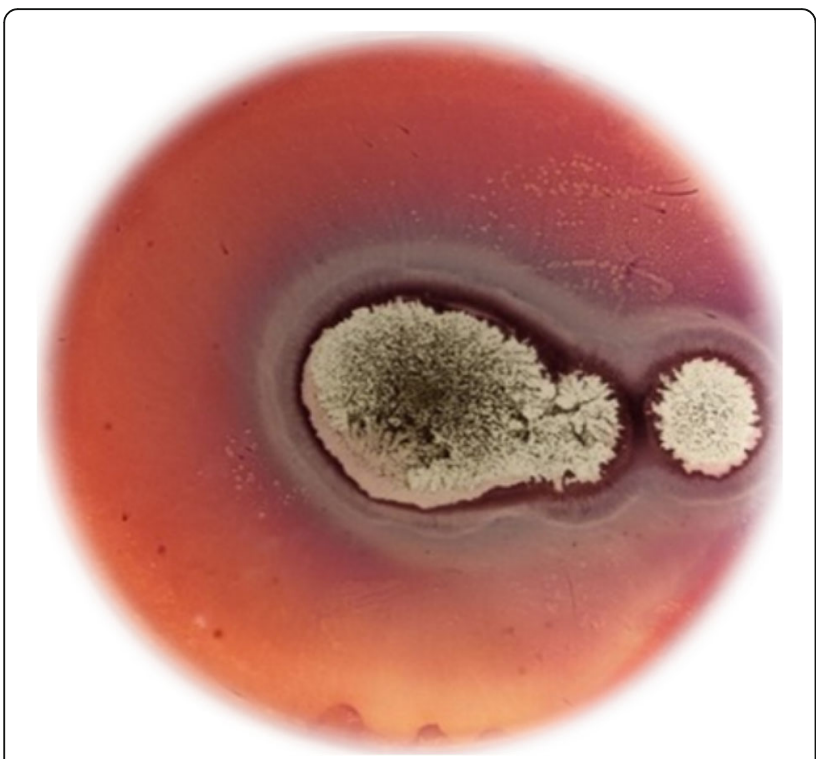

Fig. 1 Cellulase activity of Aspergillus niger in plate agar medium

by-products may be considered as a good source of enzymes (amylase, cellulase, and lipase).

Semiquantification of extracellular enzymes from $A$. niger The extracellular enzymatic activity of Aspergillus niger strains obtained by the API-ZYM system is reported in Table 2. The reactions obtained showed that all 5 strains shared almost similar enzymatic activities. Hence, lipase (C14), cystine arylamidase, trypsin, $\beta$-glucuronidase, $\alpha$ mannosidase, and $\alpha$-fucosidase were uniformly absent in all the isolates, while all isolates showed strong activity of phosphatase acid and Naphthol-AS-BI-phosphohydrolase, intermediate levels of phosphatase alkaline, esterase (C4), esterase lipase (C8), and leucine arylamidase. These fungi were characterized by the production of some enzymes taking part in carbohydrate hydrolysis ( $\alpha$-glucosidase, $\beta$-glucosidase, $\mathrm{N}$-acetyl- $\beta$-glucosaminidase), and to a lower degree $\alpha$-galactosidase and $\beta$-galactosidase enzymes. Aspergillus niger ASP2 was selected for their high production of various enzymes and used in a future experiment.

\section{Quantitative evaluation of amylase and cellulase activities Quantification of amylase and cellulase activities}

The quantification of amylase and cellulase activities from A. niger ASP2 was measured in the supernatant by the DNS method. The result demonstrated the ability of A. niger ASP2 to produce amylase and cellulase enzymes with activities of $8.37 \pm 0.09$ and $1.76 \pm 0.09 \mathrm{U} / \mathrm{mL}$, respectively. On the other hand, the biomass growth after 7 days of incubation at $25{ }^{\circ} \mathrm{C}$ in amylase and cellulase activities was $1.17 \pm 0.10$ and $1.47 \pm 0.09 \mathrm{~g} / \mathrm{L}$, respectively. The amylase activity of $A$. niger ASP2 was significantly $(p<0.05)$ higher than of the cellulase activity.

Table 2 Enzymes released by Aspergillus niger detected by the APY-ZYM ${ }^{\oplus}$ system

\begin{tabular}{|c|c|c|c|c|c|}
\hline \multirow[t]{2}{*}{ Enzymes } & \multicolumn{5}{|c|}{ Strains } \\
\hline & ASP2 & ASP6 & ASP28 & ASP31 & ASP32 \\
\hline Phosphatase alkaline & 5 & 1 & 5 & 4 & 1 \\
\hline Esterase (C4) & 5 & 2 & 5 & 4 & 2 \\
\hline Esterase lipase (C8) & 5 & 2 & 5 & 4 & 1 \\
\hline Lipase (C14) & 0 & 0 & 0 & 0 & 0 \\
\hline Leucine arylamidase & 4 & 2 & 3 & 2 & 1 \\
\hline Valine arylamidase & 2 & 0 & 0 & 0 & 0 \\
\hline Cystine arylamidase & 0 & 0 & 0 & 0 & 0 \\
\hline Trypsin & 0 & 0 & 0 & 0 & 0 \\
\hline Chymotrypsin & 2 & 0 & 0 & 2 & 0 \\
\hline Phosphatase acid & 5 & 5 & 5 & 4 & 4 \\
\hline Naphthol-AS-BI-phosphohydrolase & 5 & 4 & 4 & 5 & 3 \\
\hline a-Galactosidase & 2 & 1 & 0 & 1 & 0 \\
\hline$\beta$-Galactosidase & 2 & 1 & 0 & 0 & 0 \\
\hline$\beta$-Glucuronidase & 0 & 0 & 0 & 0 & 0 \\
\hline a-Glucosidase & 3 & 1 & 2 & 2 & 0 \\
\hline$\beta$-Glucosidase & 5 & 4 & 4 & 4 & 3 \\
\hline$N$-acetyl- $\beta$-glucosaminidase & 4 & 5 & 4 & 4 & 3 \\
\hline a-Mannosidase & 0 & 0 & 0 & 0 & 0 \\
\hline a-Fucosidase & 0 & 0 & 0 & 0 & 0 \\
\hline
\end{tabular}

The scale of the API-ZYM ${ }^{\oplus}$ test was used for enzyme quantification, with $0=$ not detected activity, $1=5$ nmol substrate metabolized, $2=10$ nmol, $3=20$ nmol, $4=$ $30 \mathrm{nmol}$, and $5 \geq 40 \mathrm{nmol}$ 


\section{Effect of initial $\mathrm{pH}$}

The results of the levels of amylase and cellulase activities obtained in different initial $\mathrm{pH}$ are presented in Fig. 2. The maximum level of amylase $(9.63 \mathrm{U} / \mathrm{mL})$ was reached at $\mathrm{pH} 5$, while $4.21 \mathrm{U} / \mathrm{mL}$ was obtained for cellulase at $\mathrm{pH} 6$ from $A$. niger ASP2. The amylase activity of $A$. niger ASP2 was significantly $(p<0.05)$ higher than of the cellulase activity in the all initial $\mathrm{pH}$ studied.

\section{Effect of temperature}

The amylase and cellulase activities obtained at different temperatures of incubation from A. niger ASP2 are reported in Fig. 3. The maximum production of cellulase and amylase enzymes for ASP2 strains tested were recorded at $30{ }^{\circ} \mathrm{C}$ with $3.76 \mathrm{U} / \mathrm{mL}$ of cellulase and $9.5 \mathrm{U} /$ $\mathrm{mL}$ of $\alpha$-amylase productions (Fig. 3). The amylase and cellulase activities of $A$. niger ASP2 at $30{ }^{\circ} \mathrm{C}$ were significantly $(p<0.05)$ higher than other temperatures studied. Moreover, the amylase activity was significantly $(p<0.05)$ higher than of the cellulase activity in all temperatures values. This activity decreases drastically when the incubation temperature exceeded $40{ }^{\circ} \mathrm{C}$. This shows clearly that the production of these enzymes by $A$. niger strains is greatly affected by this parameter.

\section{Effect of incubation time}

The effect of incubation time in the production of amylase and cellulase activities of $A$. niger ASP2 reached their maximum after $96 \mathrm{~h}$ of fermentation at $25{ }^{\circ} \mathrm{C}$ (Fig. 4). The activities of amylase and cellulase production were 10.50 and $4.47 \mathrm{U} / \mathrm{mL}$, respectively.

\section{Discussion}

The Aspergillus strains isolated from date by-products demonstrated the ability to produce various enzymes such as amylase, cellulase, and lipase. The studies of Mostafa et al. [8] and Sattar et al. [12] demonstrated the

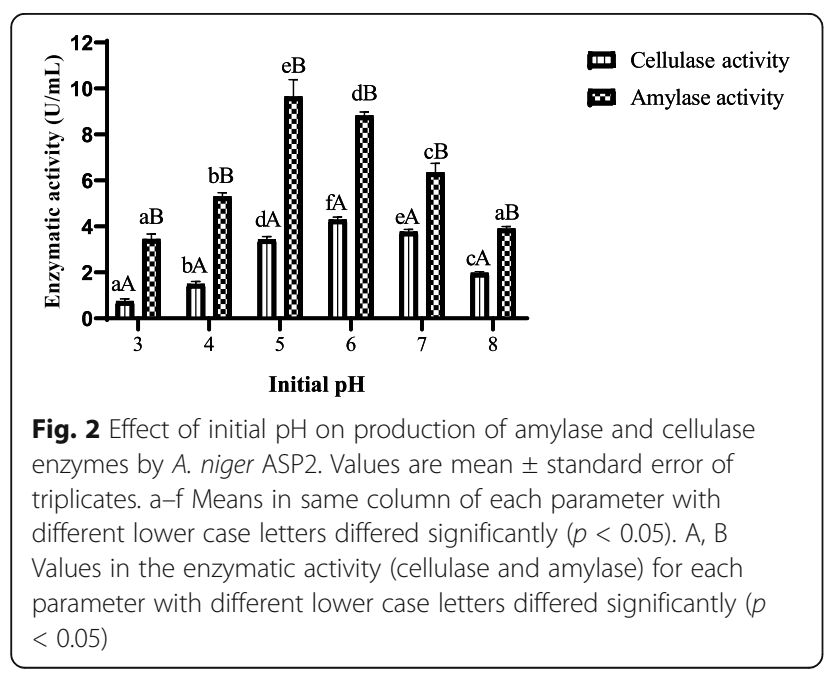

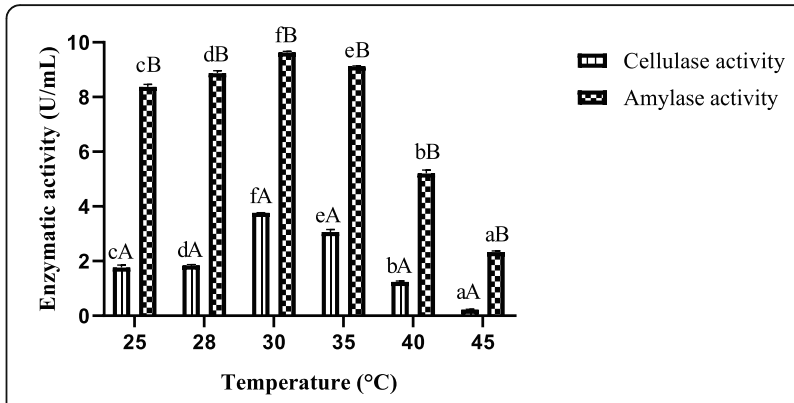

Fig. 3 Effect of incubation temperature on production of amylase and cellulase enzymes A. niger ASP2. Values are mean \pm standard error of triplicates. a- $f$ Means in same column of each parameter with different lower case letters differed significantly $(p<0.05)$. A, B Values in the enzymatic activity (cellulase and amylase) for each parameter with different lower case letters differed significantly $(p$ $<0.05)$

ability of Aspergillus to produce several enzymes. The synthesis of enzymes may also be due to the mycelial condition/age [13], and the type of enzyme produced may vary with the environmental conditions, particularly the type of substrate [14].

The semiquantitative enzyme production demonstrated the important enzymatic profile of selected Aspergillus strains from date by-products. Variable results measured by API-ZYM tests have been reported in other filamentous fungi, including Penicillium and Verticillium isolates $[15,16]$. This result indicates that the enzymes produced by $A$. niger are extracellular.

The initial pHs 5 and 6 showed the high production rate of amylase and cellulase enzymes produced by $A$. niger ASP2. Similar results are obtained with $A$. ochraceus and $A$. niger $[17,18]$. Other authors reported optimal acidic $\mathrm{pHs}$ for amylases from $A$. niger $[19,20]$. The initial $\mathrm{pH}$ of 5.5 showed the high production of cellulase enzyme from fungi [8]. The $\mathrm{pH}$ plays an important role in microbial growth, and the change in $\mathrm{pH}$ from the optimum to extreme levels results in the inactivation of the enzymes of the organisms which hinders saccharification [21]. This finding is important to the

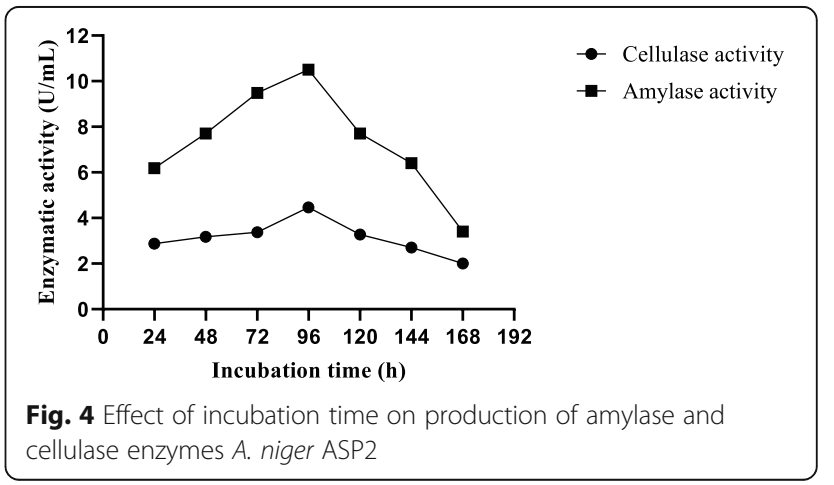


fermentation process because of its contribution to the inhibition of contaminations caused by neutrophil bacteria.

The temperature of the high production of amylase and cellulase enzymes was demonstrated at $30{ }^{\circ} \mathrm{C}$. These results are in agreement with Varalakshmi et al. [22] indicating that the best enzyme production in $A$. niger is obtained at room temperature both in submerged fermentation (SmF) and solid-state fermentation (SSF). Various studies reported that this parameter is very important during the enzymatic production, and they found that $30{ }^{\circ} \mathrm{C}$ is the optimal temperature for some fungus, especially Aspergillus species [23, 24]. However, the optimal production of crude cellulase was determined at $40{ }^{\circ} \mathrm{C}$ [25]. Also, Mostafa et al. [8] demonstrated that the production of cellulase from fungus was obtained at $60{ }^{\circ} \mathrm{C}$. On the other hand, the amylase production from $A$. clavatus achieved the maximum at 30 ${ }^{\circ} \mathrm{C}$ [9]. The temperature plays an important factor in the production of amylase and cellulase enzymes.

The maximum production level of amylase and cellulase enzymes was detected after $96 \mathrm{~h}$ of fermentation at $25{ }^{\circ} \mathrm{C}$. This result is in agreement with previous studies reported by Acharya et al. [26] and Devanathan et al. [27]. This finding was comparable to those obtained from A. clavatus [9]. However, Sulyman et al. [25] reported that the maximum production of cellulase was detected at $120 \mathrm{~h}$. The decreased activity obtained after this period was probably due to catabolite repression by glucose released from starch and CMC hydrolysis. It can also be due to the depletion of nutrients, lag phase of fungi, and production of proteases in the fermentation medium [28].

A. niger ASP2, isolated from date paste, demonstrated a high and important production of several enzymes, including amylase and cellulase enzymes. The study of some parameters $\left(\mathrm{pH}, \mathrm{T}{ }^{\circ} \mathrm{C}\right.$, and incubation time), influencing the maximum production of amylase and cellulase enzymes, this finding could be used in the valorization and the production of enzymes by fermentation of different agro-industrial residues.

\section{Conclusion}

Aspergillus niger ASP2 strain isolated from date byproduct demonstrated the production of extracellular enzymes such as amylase, cellulase, and lipase. A. niger ASP2 strain isolated from date paste showed the high production rate of these enzymes (amylase, cellulase, and lipase) in plate agar medium. Therefore, the highest production was recorded in initial $\mathrm{pH} 5$ and $\mathrm{pH} 6$ for amylase and cellulase, respectively. The maximum production of amylase and cellulase enzymes was demonstrated at a temperature of $30{ }^{\circ} \mathrm{C}$ and after $96 \mathrm{~h}$ of incubation. This fungus isolated from undervalued date by-products can produce several extracellular enzymes using the carbon source contained in different agroindustrial residues.

\section{Abbreviations}

$\mathrm{NaCl}$ : Sodium chloride; pH: Hydrogen potential; UV: Ultraviolet; TDF: Total dietary fibers; PDA: Potato dextrose agar; CMC: Carboxymethylcellulose

\section{Acknowledgements}

The authors are grateful to the National Center for Scientific and Technical Research-Rabat Morocco (CNRST), for supporting this research. Special thanks are due to Dr. Ikram MERCHA for proofreading and English editing of the manuscript.

\section{Authors' contributions}

AA selected the scope of the work and supervised the lab work. RB, HA, YR, and $A H$ conducted the experiments; $A A, N G, A H, A B$, and $R B$ wrote the manuscript. All authors read and approved the manuscript.

Funding

Not applicable

\section{Availability of data and materials}

All data generated or analyzed during this study are included in this article.

\section{Declarations}

\section{Ethics approval and consent to participate}

This article does not contain any studies with human participants or animals performed by any of the authors.

\section{Consent for publication}

Not applicable

\section{Competing interests}

The authors declare that they have no competing interests.

\section{Author details}

${ }^{1}$ Laboratory of Bioresources, Biotechnology, Ethnopharmacology and Health, Faculty of Sciences, Mohammed Premier University, 60000 Oujda, Morocco. ${ }^{2}$ National Institute of Agronomic Research (INRA), Oujda Center, 60000 Oujda, Morocco.

Received: 25 October 2020 Accepted: 12 March 2021 Published online: 31 March 2021

\section{References}

1. Berka RM, Dunn-Coleman N, Ward M (1992) Industrial enzymes from Aspergillus species. Biotechnol 23:155

2. Pandey A, Selvakumar P, Soccol CR, Poonam Nigam (1999) Solid-state fermentation for the production of industrial enzymes. Curr Sci:149-162

3. Coutinho PM, Andersen MR, Kolenova K, vanKuyk PA, Benoit I, Gruben BS, Trejo-Aguilar B, Visser H, van Solingen P, Pakula T (2009) Post-genomic insights into the plant polysaccharide degradation potential of Aspergillus nidulans and comparison to Aspergillus niger and Aspergillus oryzae. Fungal Genet Biol 46(1):S161-S169. https://doi.org/10.1016/j.fgb.2008.07.020

4. de Vries RP, Visser J (2001) Aspergillus enzymes involved in degradation of plant cell wall polysaccharides. Microbiol Mol Biol Rev 65(4):497-522. https://doi.org/10.1128/MMBR.65.4.497-522.2001

5. Bellaouchi R, Ghomari I, Hasnaoui A, Hakkou A, Bechchari A, Chihib NE, Asehraou A (2017) Physico-chemical and microbial properties of undervalued dates and processed dates by-products in Morocco. Int Food Re J 24:963-969

6. Hasnaoui A, ElHoumaizi MA, Asehraou A, Sindic M, Deroanne C, Hakkou A (2010) Chemical composition and microbial quality of dates grown in Figuig oasis of Morocco. Int J Agric Biol 12:311-314

7. Hasnaoui A, Elhoumaizi MA, Borchani C, Attia H, Besbes S (2012) Physicochemical characterization and associated antioxidant capacity of fiber concentrates from Moroccan date flesh. Indian J Sci Technol 5:2954-2960

8. Mostafa FA, Abd AA, Aty E, Hamed ER, Eid BM, Ibrahim NA (2016) Enzymatic, kinetic and anti-microbial studies on Aspergillus terreus culture 
filtrate and Allium cepa seeds extract and their potent applications. Biocatal Agric Biotechnol 5:116-122. https://doi.org/10.1016/j.bcab.2016.01.005

9. Shruthi BR, Achur RNH, Boramuthi TN (2020) Optimized solid-state fermentation medium enhances the multienzymes production from Penicillium citrinum and Aspergillus clavatus. Curr Microbiol 77(9):2192-2206. https://doi.org/10.1007/s00284-020-02036-w

10. Hultin K, Nordstrom L (1949) Investigations on dextranase. I. On the occurrence and the assay of dextranase. Aeta Chem Scand 3:1405-1417. https://doi.org/10.3891/acta.chem.scand.03-1405

11. Miller GL (1959) Use of dinitrosalicylic acid reagent for determination of reducing sugar. Anal Chem 31(3):426-428. https://doi.org/10.1021/ac60147a 030

12. Sattar H, Bibi Z, Kamran A, Aman A, Qader SAU (2019) Degradation of complex casein polymer: production and optimization of a novel serine metalloprotease from Aspergillus niger KIBGE-IB36. Biocatal Agric Biotechnol 21:101256. https://doi.org/10.1016/j.bcab.2019.101256

13. Yabuki M, Ono N, Hoshino K, Fukui S (1977) Rapid induction of alphaamylase by nongrowing mycelia of Aspergillus oryzae. Appl Environ Microbiol 34(1):1-6. https://doi.org/10.1128/AEM.34.1.1-6.1977

14. Bagyaraj DJ, Rangaswami G (2007) Agricultural microbiology. PHI Learning Pvt. Ltd, Delhi

15. Bridge PD, Hawksworth DL (1984) The API ZYM enzyme testing system as an aid to the rapid identification of Penicillium isolates. Microbiol Sci 1(9): 232-234

16. Williams MAJ, Brady BL, Bridge PD, Paterson RRM (1992) Biochemical and physiological tests as aids to identification of Verticillium section Nigrescentia. Mycopathologia 119(2):101-114. https://doi.org/10.1007/ BF00443941

17. Nahas E, Waldemarin MM (2002) Control of amylase production and growth characteristics of Aspergillus ochraceus. Rev Latinoam Microbiol 44:5-10

18. Hernández MS, Rodriguez MR, Guerra NP, Rosés RP (2006) Amylase production by Aspergillus niger in submerged cultivation on two wastes from food industries. J Food Eng 73(1):93-100. https://doi.org/10.1016/j. jfoodeng.2005.01.009

19. Uguru GC, Akinyanju JA, Sani A (1997) The use of yam peel for growth of locally isolated Aspergillus niger and amylase production. Enzym Microb Technol 21(1):48-51. https://doi.org/10.1016/S0141-0229(96)00225-6

20. Mitidieri S, Martinelli AHS, Schrank A, Vainstein MH (2006) Enzymatic detergent formulation containing amylase from Aspergillus niger: a comparative study with commercial detergent formulations. Bioresour Technol 97(10):1217-1224. https://doi.org/10.1016/.biortech.2005.05.022

21. Grover A, Maninder A, Sarao LK (2013) Production of fungal amylase and cellulase enzymes via solid state fermentation using Aspergillus oryzae and Trichoderma reesei. Int J Adv Res Technol 2:108-124

22. Varalakshmi KN, Kumudini BS, Nandini BN, Solomon J, Suhas R, Mahesh B, Kavitha AP (2009) Production and characterization of a-amylase from Aspergillus niger JGI 24 isolated in Bangalore. Pol J Microbiol 58(1):29-36

23. Alva S, Anupama J, Savla J, Chiu YY, Vyshali P, Shruti M, Yogeetha BS, Bhavya D, Purvi J, Ruchi K (2007) Production and characterization of fungal amylase enzyme isolated from Aspergillus sp. JGI 12 in solid state culture. Afr J Biotechnol 6:576

24. Gupta A, Gupta VK, Modi DR, Yadava LP (2008) Production and characterization of a-amylase from Aspergillus niger. Biotechnol 7(3):551-556. https://doi.org/10.3923/biotech.2008.551.556

25. Sulyman AO, Igunnu A, Malomo SO (2020) Isolation, purification and characterization of cellulase produced by Aspergillus niger cultured on Arachis hypogaea shells. Heliyon 12:e05668

26. Acharya PB, Acharya DK, Modi HA (2008) Optimization for cellulase production by Aspergillus niger using saw dust as substrat. Afr J Biotechnol 7

27. Devanathan G, Shanmugam A, Balasubramanian T, Manivannan S (2007) Cellulase production by Aspergillus niger isolated from coastal mangrove debris. Trends Appl Sci Res 2:23-27

28. Haq I, Ashraf H, Rani S, Qadeer MA (2002) Biosynthesis of alpha amylase by chemically treated mutant of Bacillus subtilis GCBU-20. Pak J Biol Sci 2:73-75

\section{Publisher's Note}

Springer Nature remains neutral with regard to jurisdictional claims in published maps and institutional affiliations.

\section{Submit your manuscript to a SpringerOpen ${ }^{\circ}$ journal and benefit from:}

- Convenient online submission

- Rigorous peer review

- Open access: articles freely available online

- High visibility within the field

- Retaining the copyright to your article

Submit your next manuscript at $\boldsymbol{\triangleright}$ springeropen.com 